\title{
Periode Pemijahan Spons Aaptos aaptos (Porifera: Demospongia) di Perairan Pulau Pari, Kepulauan Seribu, DKI Jakarta
}

\author{
Spawning Period of Sponge Aaptos aaptos (Porifera : Demospongia) at Pari Island, \\ Thousand Islands, Jakarta
}

\author{
Mujizat Kawaroe*, Dedi Soedharma, Rahmadsyah Deny Siregar \\ Bagian Biologi dan Keanekaragaman Hayati Laut, Fakultas Perikanan dan Ilmu Kelautan, Institut Pertanian \\ Bogor, Bogor, 16680 \\ E-mail: mujizat@ipb.ac.id *Penulis untuk korespondensi
}

\begin{abstract}
The purpose of this research was to study spawning period of sponge Aaptos aaptos at Pari Island, Thousand Islands, DKI Jakarta. The result showed that spawning time occurred at 17.00-18.00, and within that time the sponge closed their osculum to throw out the zygote leaving the body faster. The duration of spawning range from 4 minutes to 41 minutes. Based on the lunar periode, spawning for sponge Aaptos aaptos started from early new moon till few days after full moon. Spawning mostly took place during spring tides. Based on the PCA analysis, it was found that water temperature and pressure had strong correlation with spawning time.
\end{abstract}

Key words: spawning, Aaptos aaptos, sponge, Pari Island, lunar periode

Diterima: 01 Oktober 2007, disetujui: 22 Januari 2008

\section{Pendahuluan}

Biologi reproduksi beberapa spesies spons yang berasal dari lautan bermusim empat telah banyak diteliti tetapi sangat sedikit spesies yang dapat diketahui dengan rinci hasilnya (Sara, 1992). Penelitian tentang reproduksi spons yang berasal dari laut tropis terutama Indonesia baru satu kali dilakukan yaitu oleh Haris (2005) tetapi terbatas masih pada pengamatan histologis. Secara umum banyak aspek reproduksi spons laut, khususnya tentang sitodiferensiasi gamet, telah diteliti pada beberapa spesies (Simpson, 1984; Gaino et al., 1986; Sara, 1992; Fell, 1993; Gaino dan Sara, 1994; Corriero et al., 1998; Ereskovsky, 2000).

Penelitian pemijahan sperma, telur, zygot, dan larva secara langsung di alam dan pengaruh parameter lingkungan pada saat proses tersebut berlangsung masih belum pernah dilakukan di Indonesia. Padahal secara ekologis spons merupakan organisme laut yang sangat penting di ekosistem terumbu karang (De Voodg, 2005). Sponge merupakan komponen utama dari komunitas terumbu karang dan berperan sama baiknya dengan biota lain di perairan pesisir dan laut dalam. Pada ekosistem laut, fungsi utama interaksi organisme berasal dari sponge karena dapat menyaring dengan jumlah yang sangat besar bahan organik yang berasal dari perairan disekitarnya. Setiap hari, dengan jumlah volume air yang setara dengan $20.000 \mathrm{~m}^{2}(40$ meter (dalam) dan $500 \mathrm{~m}$ (lebar) pada kolom air) dapat disaring oleh populasi sponge yang terdapat di terumbu karang (Reiswig, 1974dalam Tomascik et al., 1997). Proses pemijahan yang sudah sering diamati adalah yang dilakukan oleh karang dan juga teramati beberapa spesies spons melakukan reproduksi sepanjang tahun (Reiswig, 1973 dalam Sidri, 2005). Penelitian lain yang dilakukan di Laut Mediteranean (subtropis) menunjukkan bahwa perkembangan gamet dan pemijahan murni dipengaruhi oleh perubahan suhu dan sangat sulit diramalkan 
terjadinya. Menurut Simpson (1984), sebagian besar hasil penelitian reproduksi sponge yang telah dilakukan menunjukan bahwa tipe reproduksinya adalah vivipar (fertilisasi terjadi di dalam) dan masih sedikit yang diketahui bertipe ovipar (fertilisasi terjadi di luar) (Mariani et al., 2000). Tipe vivipar spons memudahkan dalam melakukan pengamatan untuk mengetahui siklus hidup spons melalui perkembangan dan pengeluaran larvanya, karena yang di pijahkan adalah yang sudah berbentuk larva (Gaino et al., 1987). Dan menurut Sidri et al., (2005), sulitnya mengidentifikasi tipe reproduksi spons (vivipar atau ovipar) karena tidak mudah untuk menemukan spons yang sedang melakukan reproduksi dan juga menemukan tempat dan waktu yang tepat pada saat spons melakukan pemijahan.

Beberapa spesies spons lain seperti Chondrilla nucula di Mediteranean melakukan reproduksi secara seksual dan aseksual. Tipe reproduksi seksual spons in adalah ovipar dimana fertilisasi terjadi di luar tubuh. Sedangkan reproduksi aseksualnya dilakukan dengan cara fragmentasi, yang memungkinkan spons dengan cepat dapat menyebar di substrat dan membentuk koloni yang lebih besar. (Brummer et al., 2003; Sidri, 2004). Spesies ini memiliki cara reproduksi gonokhoris dan ovipar, akan tetapi pengeluaran gamet dan perkembangan larvanya belum diteliti (BouryEsnault, 2002). Pada spons ovipar lain seperti Polymastia robusta menunjukkan bahwa yang dipijahkan adalah zigot dan embrio yang dikeluarkan ke kolom air (Simpson, 1984).

Ritson-Wiliam et al., (2005), menjelaskan bahwa spons raksasa Xetospongia muta menempelkan hasil pemijahannya pada karang penghalang (barrier reef), di Selatan Carrie Bow, Belize. Spons jenis ini diamati pada bagian dalam slope karang (kedalaman 10-20 m) dan di depan slope karang (kedalaman 15$60 \mathrm{~m}$ ). Hasil penelitian tersebut menunjukkan bahwa hanya pada spons yang berada di depan slope karang (kedalaman $20 \mathrm{~m}$ ) yang melakukan pemijahan. Tipe pemijahan spons jenis ini adalah synchronous, yaitu individu jantan dan betina terdiri dari berbagai ukuran. Pemijahan terjadi mulai pukul 08.00 pagi sampai 09.00 pagi. Telur-telur yang dikeluarkan tidak mengambang tetapi terakumulasi dan menempel pada atrium spons dan selanjutnya tersebar pada organisme bentik yang berada di sekitar spons. Sedangkan sperma mengambang seperti awan pada kolom air.

Walaupun sponge di terumbu karang Carribean merupakan komponen utama, tetapi masih sedikit pengetahuan tentang waktu terjadinya pemijahan (Fell, 1993). Di Curacao, sponge Neofibularia nolitangere memiliki tipe pemijahan syncronous yang memijah pada sore hari di bulan Oktober dan Nopember (3 hari setelah bulan purnama /bulan penuh) (Hoppe dan Reichert, 1987; Hoppe, 1988).

Faktor ekologi yang seringkali diasumsikan mempengaruhi proses reproduksi spons, khususnya pada proses pemijahan, antara lain adalah suhu (Kaye dan Reiswig, 1991; Witte et al., 1994). Suhu merupakan faktor yang sangat berpengaruh terhadap proses pemijahan pada spons yang berada di daerah subtropis. Variasi perubahan faktor lingkungan juga mempengaruhi reproduksi spons seperti misalnya waktu pemijahan (Meros-Fine et al., 2005). Banyak hasil penelitian menunjukkan bahwa perubahan suhu secara musiman merupakan faktor lingkungan utama yang mempengaruhi siklus reproduksi tahunan (Fan dan Dai, 1999; Fromont, 1994; Meros-Fine dan Ilan, 1995). Walaupun sulit diduga, suhu dan kemungkinan, siklus bulan merupakan faktor pemicu terjadinya proses pemijahan oleh Chondrilla australiensis (Usher et al., 2001).

Penelitian ini bertujuan untuk mengkaji periode pemijahan spons jenis Aaptos aaptos, kondisi kualitas air pada saat terjadinya pemijahan, dan pengaruh kondisi kualitas air terhadap frekuensi pemijahan.

\section{Metode Penelitian}

Penelitian dilakukan pada tanggal 14 Juni sampai 11 Juli 2006 di Pulau Pari, Kepulauan Seribu, DKI Jakarta. Pengambilan contoh dilakukan pada pukul 16.00-20.00 WIB dengan cara menangkap hasil pemijahan dengan menggunakan plastik contoh. Selanjutnya contoh yang diperoleh diawetkan dengan menggunakan lugol dan kemudian diamati dengan mikroskop. Data suhu diukur 
dengan menggunakan termometer, kecerahan diukur dengan sechii disk, salinitas diukur dengan menggunakan refraktometer, sedangkan data tekanan diperoleh rumus: $P=\rho . g . z(P=$ Tekanan $\left(\mathrm{N} / \mathrm{m}^{2}\right) ; \rho=$ Massa air laut $\left(1.03 \times 10^{3}\right.$ $\left.\mathrm{kg} / \mathrm{m}^{3}\right) ; g=$ Gravitasi $\left(9.8 \mathrm{~m} /{ }^{2}\right) ; z=$ Kedalaman (m) kedalaman kolom air diperoleh dari selisih tinggi muka air laut pukul 16.00 WIB dengan 20.00 WIB.

Pengolahan data dilakukan dengan menggunakan software Statistika 6 (Principle Component Analysis) dan Microsoft Excel.

\section{Hasil dan Pembahasan}

Hasil penelitian menunjukkan bahwa frekuensi pemijahan paling sering terjadi sesaat sebelum dan sesudah matahari terbenam yaitu pada pukul 17.00-18.00 WIB. Hasil pemijahan yang keluar menyerupai mukus transparan dan dengan cepat dikeluarkan dari oskulum. Sebelum mengeluarkan, oskulum akan mengecil untuk menutup lubangnya dan tingkah laku oskulum yang menutup adalah sedang berkontraksi untuk menyemburkan gamet (Gambar 1). Hasil semburan tersebut akan melayang ke kolom air, untuk selanjutnya menyebar terbawa oleh arus. Tingkah laku pemijahan spons Aaptos aaptos memperlihatkan bahwa gamet yang dilepaskan melayang di kolom air sekitar 5-10 detik sebelum tercampur dengan air laut. Berdasarkan pengamatan dengan mikroskop diduga gamet yang dikeluarkan adalah telur yang telah dibuahi (zigot). Dugaan ini diperkuat dengan gambar telur yang diperoleh secara histologis yang memiliki bentuk hampir sama (Gambar 3). Hasil ini menunjukkan bahwa tingkah laku fertilisasi spons jenis Aaptos aaptos ini terjadi secara internal dimana telur yang akan dikeluarkan telah dibuahi oleh sperma menjadi zigot. Selama penelitian tidak pernah terlihat gamet jantan (sperma) yang dikeluarkan pada saat pemijahan.

Waktu pemijahan Aaptos aaptos dominan terjadi pada pukul 17.00-18.00 WIB (Gambar 2) yaitu pada saat matahari akan terbenam, dan periode setiap pemijahan berkisar 4 - 41 menit, dan rata-rata periode pemijahan yang sering terjadi pada saat pengamatan adalah $5-6$ menit. Waktu pemijahan pada sponge berbeda dengan karang, soft coral dan gorgonian karena sponge seringkali memijah pada sore dan malam hari. Hal ini disebabkan karena pada sore dan malam hari suhu semakin menurun sehingga hasil pemijahan lebih aman dan terhindar dari predator yang memangsanya karena tidak terlihat. Karang Acropora nobilis memijah pada sore hari sampai menjelang tengah malam (Rani, 2004). Beberapa soft coral dan gorgonian juga memijah pada saat beberapa jam setelah matahari terbenam (Zaslow dan Benayahu, 1996 dalam Fabricius dan Alderslade, 2001).

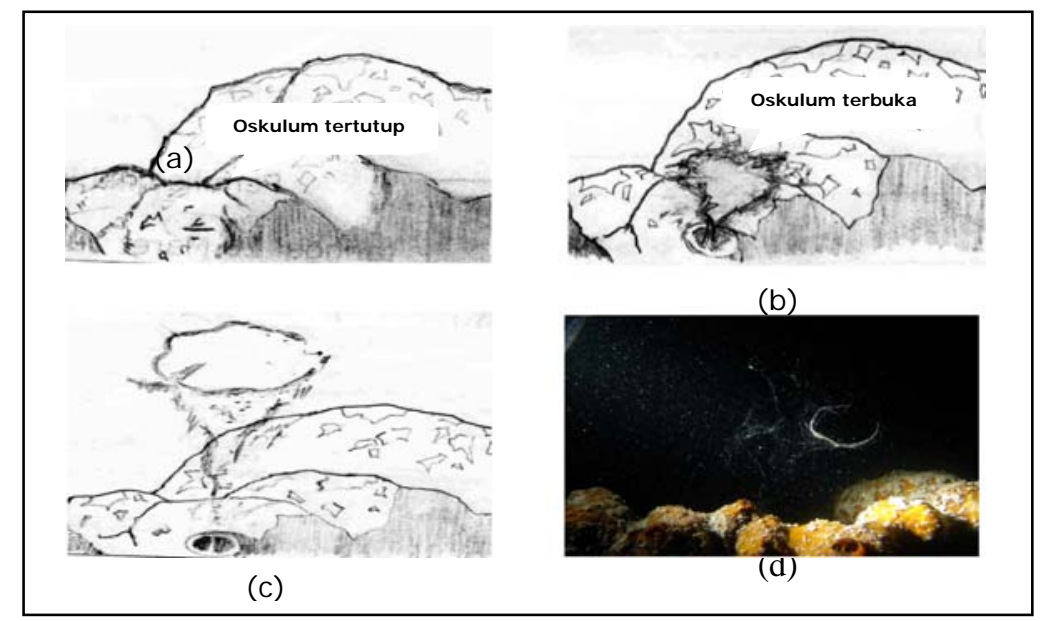

Gambar 1. Pemijahan spons jenis Aaptos aaptos

Keterangan: a. Oskulum tertutup; b. Oskulum terbuka; c. Pemijahan spons; d. Pemijahan spons 
Kawaroe et al.,

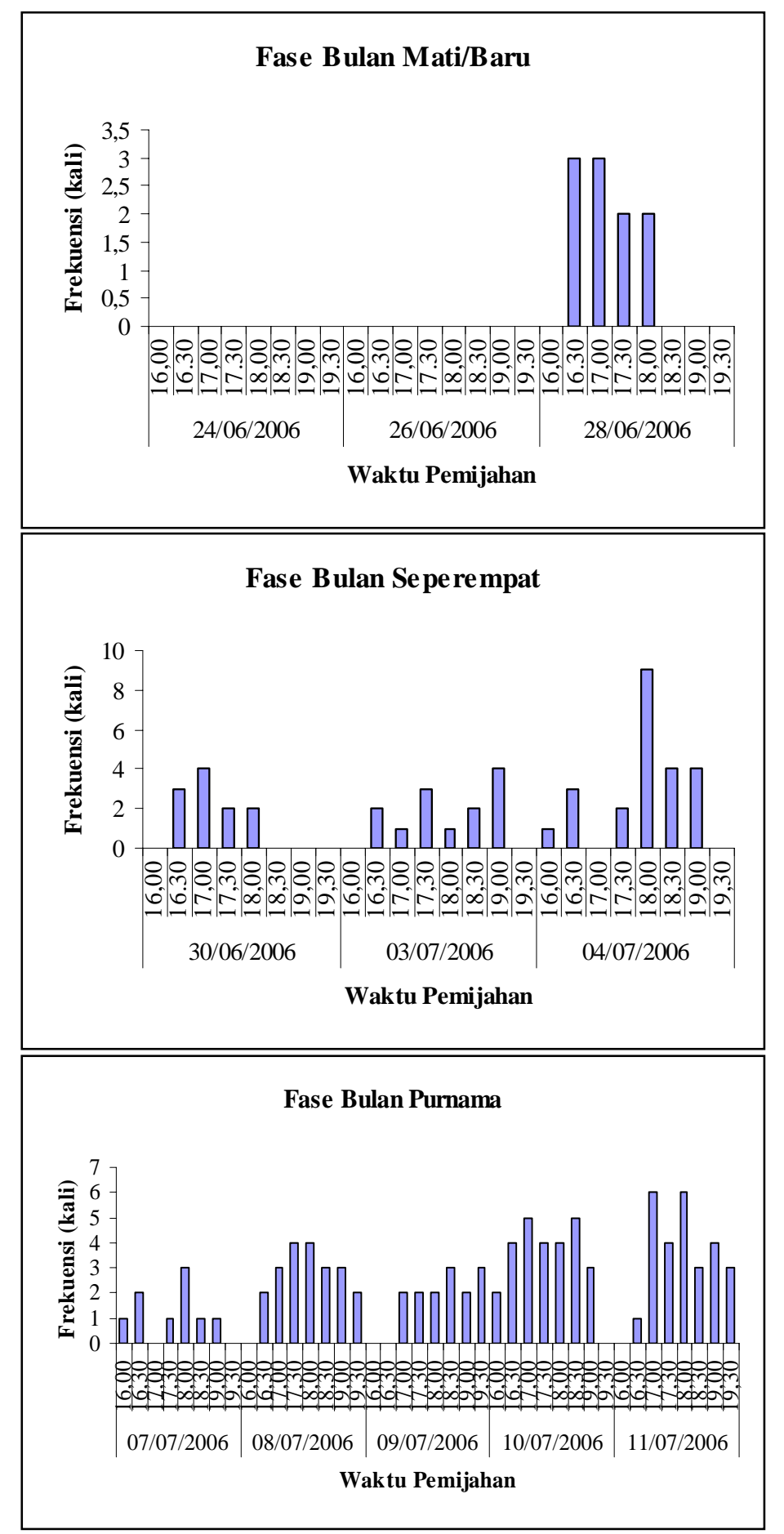

Gambar 2. Waktu pemijahan spons Aaptos aaptos setiap fase bulan

Tabel 1. Nilai Parameter Fisika Kimia dan rata-rata frekuensi pemijahan setiap fase bulan

\begin{tabular}{|c|c|c|c|c|c|c|c|c|c|c|c|}
\hline Tanggal & Fase & $\begin{array}{c}\text { Suhu } \\
\left({ }^{0} \mathrm{C}\right)\end{array}$ & $\begin{array}{c}\text { Kecerahan } \\
\text { (m) } \\
\end{array}$ & $\begin{array}{c}\begin{array}{c}\text { Salinitas } \\
(\% / 00)\end{array} \\
\end{array}$ & $\begin{array}{c}\text { DO } \\
(\mathrm{mg} / \mathrm{l})\end{array}$ & $\begin{array}{l}\begin{array}{l}\text { Nitrat } \\
(\mathrm{mg} / \mathrm{l})\end{array} \\
\end{array}$ & $\begin{array}{l}\text { Nitrit } \\
\text { (mg/l) }\end{array}$ & $\begin{array}{c}\text { Fospat } \\
(\mathrm{mg} / \mathrm{l})\end{array}$ & $\begin{array}{l}\begin{array}{l}\text { Silikat } \\
(\mathrm{mg} / \mathrm{l})\end{array} \\
\end{array}$ & $\begin{array}{c}\text { Tekanan } \\
\left(\mathbf{N} / \mathbf{m}^{2}\right)\end{array}$ & $\begin{array}{c}\begin{array}{c}\text { Frekuensi } \\
\text { (kali) }\end{array} \\
\end{array}$ \\
\hline 206 & tiga & 30.00 & 5.23 & 33.00 & 5.10 & 0.24 & 0.02 & 0.16 & 0.44 & 1917.86 & 0.00 \\
\hline & & 29.50 & & 3 & 6.80 & 0. & 1 & 0.0 & 2 & & .00 \\
\hline 3 & sepel & 29.00 & 4. & 30 & 7.40 & 0.5 & 0.01 & 0.4 & 0.39 & 22 & 1. \\
\hline $10 / 7 / 2006$ & purnama & 28.00 & 4.50 & 32.00 & 6.43 & 0.52 & 0.01 & 0.34 & 0.45 & 2220.68 & 2.45 \\
\hline
\end{tabular}


Pengamatan pada saat fase bulan tiga perempat (18 Juni 2006) dilakukan pada tanggal 14, 15, 16, 18 Juni 2006, namun tidak memperlihatkan adanya pemijahan (Gambar 2). Pada saat fase bulan mati/baru (26 Juni 2006), pemijahan terjadi pada tanggal 28 Juni 2006 tepat sehari setelah fase bulan mati/baru. Pemijahan mulai terlihat pada pukul 16.30 dan berakhir pada pukul 18.00 WIB, dan frekuensi pemijahan tertinggi terjadi pada selang pukul 16.30-17.00 WIB. Fase bulan seperempat (3 Juli 2007), terjadi pemijahan pada tanggal 30 Juni, 3, dan 4 Juli 2006 dengan selang waktu pemijahan terjadi pada pukul 16.00-19.00 WIB, dan puncak pemijahan pada pukul 17.00-19.00 WIB. Frekuensi pemijahan terbanyak terjadi pada tanggal 4 Juli 2006 tepat sehari setelah fase bulan seperempat (Gambar 2). Diduga pemijahan terjadi pada fase bulan seperempat karena gamet spons mulai matang. Sehingga frekuensi pemijahan mulai sering terlihat. Fase bulan purnama (10 Juli 2006) terlihat frekuensi pemijahan yang paling tinggi. Pemijahan terjadi pada semua tanggal pengamatan, dan frekuensi pemijahan tertinggi terjadi pada tanggal 10 dan 11 Juli 2006. Terlihat bahwa frekuensi puncak pemijahan terjadi pada pukul 17.00-19.00 WIB. Pemijahan pada fase bulan purnama diduga juga karena tingkah laku spons yang dipengaruhi oleh perubahan tekanan melalui penambahan kolom air (Tanner, 1996).

Hasil Analisis Komponen Utama terhadap beberapa parameter seperti suhu, kecerahan, salinitas, kedalaman kolom air, nitrat, nitrit, DO, silikat, dan fospat menunjukkan bahwa suhu berkorelasi erat dengan sumbu 1 dan sumbu 2 (Gambar 4). Fase bulan tiga perempat dicirikan oleh Kecerahan dan Nitrit, fase bulan mati/baru tidak dicirikan oleh variabel apapun sedangkan pada fase bulan seperempat dan fase bulan purnama dicirikan oleh variabel Fosfat dan frekuensi pemijahan. Adanya posisi sekitar $180^{\circ}$ antara frekuensi dengan suhu mengindikasikan bahwa besar frekuensi dengan suhu hubungannya berbanding terbalik dalam mempengaruhi periode pemijahan spons jenis Aaptos aaptos. Sedangkan tekanan walaupun memiliki nilai korelasi yang rendah dan tidak mencirikan suatu sumbu namun mencirikan suatu bidang dengan baik sehingga tekanan diduga merupakan salah satu faktor yang mempengaruhi periode pemijahan dengan penambahan massa air yang berbeda pada setiap fase bulannya. Hoope dan Reichert (1987) menjelaskan juga bahwa pemijahan spons jenis Neofibularia nolitangere pada daerah tropis berhubungan erat dengan fase bulan. Isyarat perubahan tekanan air dari perubahan pola pasang surut diduga bertindak sebagai isyarat penguat ketika akan berlangsung pemijahan. Dengan demikian pasang surut dan fase bulan serta interaksinya dapat menjadi faktor eksternal penting dalam menentukan waktu pelepasan gamet.

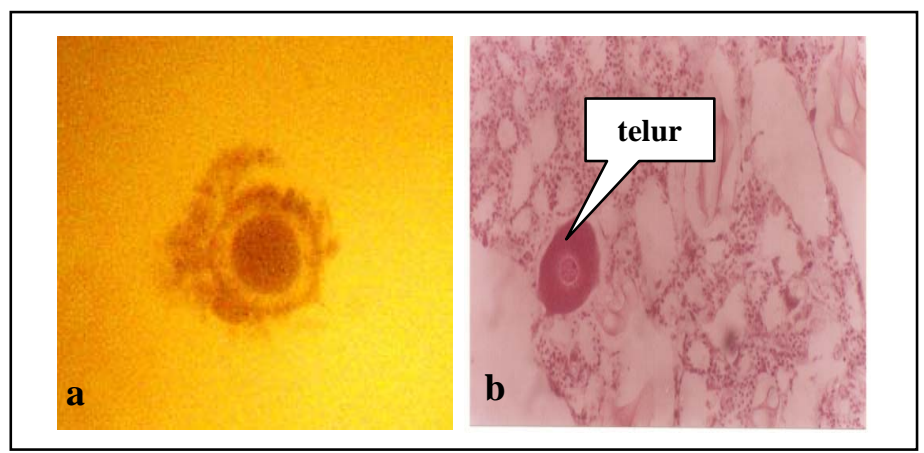

Gambar 3. (a) Telur Aaptos aaptos hasil pemijahan (mikroskop jenis student dengan pembesaran 1:40. (b) telur hasil histologis pewarnaan $\mathrm{HE}$ ) 


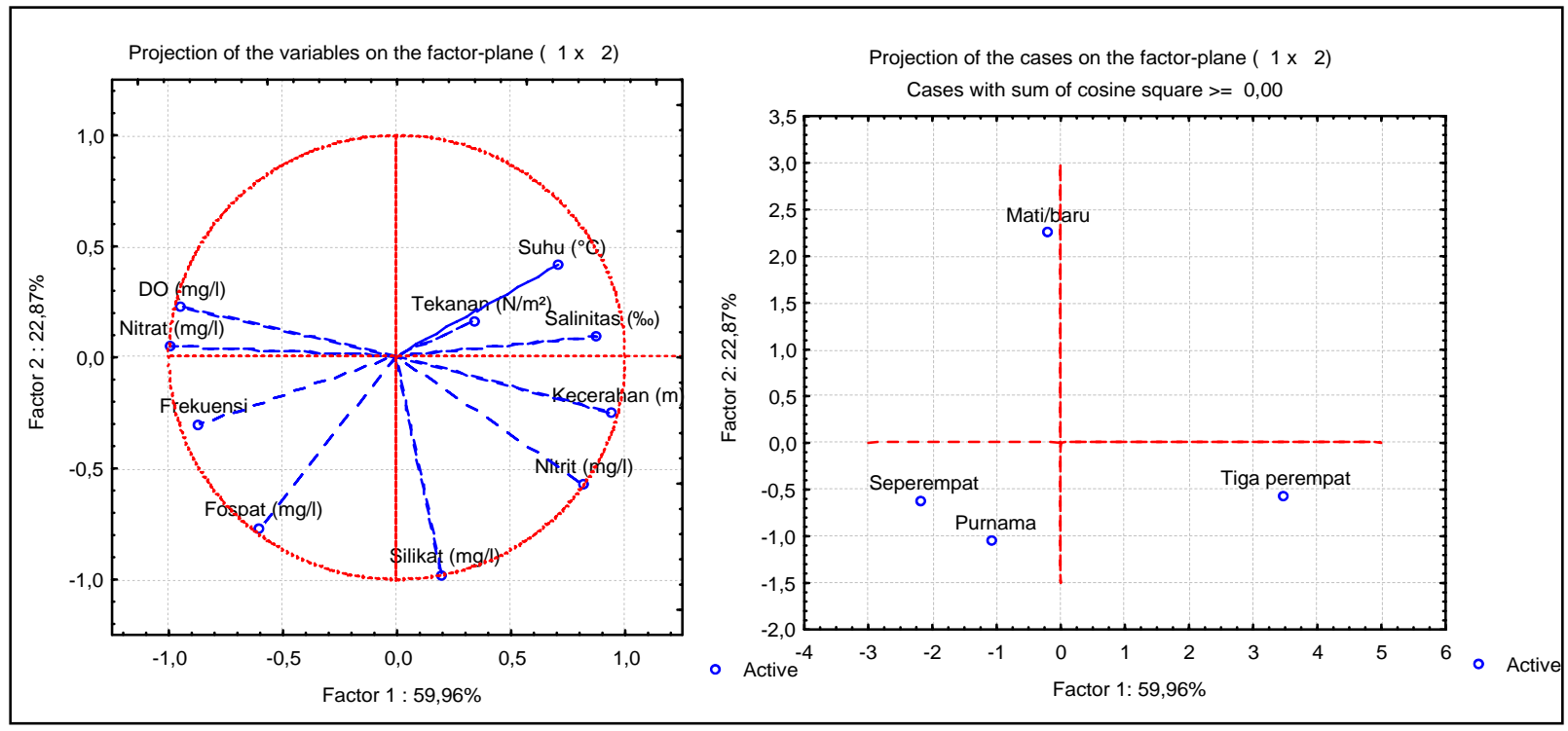

Gambar 4. PCA untuk parameter kimia perairan dan penyebaran fase bulan pada sumbu utama dan kedua (F1 $\mathrm{x}$ F2)

\section{Kesimpulan dan Saran}

\section{Kesimpulan}

Fertilisasi spons jenis Aaptos aaptos terjadi secara internal yaitu telur yang dikeluarkan telah dibuahi oleh sperma menjadi zigot. Waktu pemijahan (time spawning) Aaptos aaptos dominan terjadi pada saat matahari akan terbenam. Frekuensi pemijahan terbanyak terjadi setelah bulan seperempat. Tekanan diduga merupakan faktor yang mempengaruhi periode pemijahan

\section{Saran}

Saran yang perlu dilakukan untuk kelanjutan penelitian ini adalah waktu pengamatan diperpanjang sampai satu tahun untuk mengetahui pola pemijahan spons selama satu tahun.

\section{Ucapan Terima Kasih}

Ucapan terima kasih ditujukan kepada Direktorat Jenderal Pendidikan Tinggi (DIKTI), DEPDIKNAS atas bantuan dana penelitian melalui program penelitian Hibah Pasca No. 317/SP3/PP/DP2M/II/2006, Tim Penelitian Cumi-cumi yang membantu dalam pengamatan di lapangan, P2O LIPI Pulau Pari atas fasilitas Penginapan selama di lapangan, bagian BIODIV atas mikroskop dan alat-alat penelitian lain.

\section{Daftar Pustaka}

Brummer, F., Nickel, M. and Sidri, M. 2003. Porifera (Schwamme). In: Hofrichter, R. (Eds.). Das Mittelmeer. pp. 302-383. Spektrum Akademischer Verlag, Heidelberg, Berlin.

Boury-Esnault. 2002. Order Chondrosida BOURYESNAULT \& LOPES 1985 Family Chondrillidae GRAY 1872. In: Hooper, J.N.A. \& Van Soest, R.W.M. (Eds.). Systema Porifera: A Guide to the Classification of Sponges. Pp. 291-297. Kluwer Academic/ Plenum Publisher, New York.

Corriero, G., Liaci, L.S., Marzano, C.N. and Gaino, E. 1998. Reproductive strategy of Mycale contarenii (Porifera: Demospongia). Mar Biol. 131: 319-327.

De Voodg, N.J. 2005. Indonesian sponges: Biodiversity and marincultured potential. Netherlands: Geboren te Dodrecht.

Ereskovsky, A.V. 2000. Reproduction cycles and strategies of cold water sponges Halisacra dujardinii (Demospongiae, Halisarcida), Myxilla incrustans and Iophone piceus (Demospongia, Poecilosclerida) from the White Sea. Bioll.Bull. 198: 77-87. 
Fabricius, K. and Alderslade, P. 2001. Soft Coral and Sea Fans. AIMS. Australia: 17.

Fan, T.Y. and Dai, C.F. 1999. Reproductive Plasticity in the Reef Coral Echinophora lamellosa. Mar. Ecol. Prog. Ser. 190: 297-301.

Fell, P. 1993. Porifera. In: Adiyogi, K.G. \& Adiyogi, R.G. (Eds.). Reproductive Biology of Invertebrates: Asexual Propagation and Reproductive Strategies, Vol VI, pp. 1-44. Part A. Oxford and IBH Publishing, New Delhi.

Fromont, J. 1994. Reproductive development and timing of tropical sponges (Order Haplosclerida) from the Great Barrier Reef, Australia. Coral Reef 13: 127-133.

Gaino, E. and Sara, M. 1994. An ultrasructural comparative study of the eggs of two species of Tethya (Porifera, Demospongiae). Invert. Reprod.Dev. 26 (2): 99-106.

Gaino, E., Burlando, B. and Buffa, P. 1986. Contribution to the study of egg development and derivation in Oscarella lobularis (Porifera, Demospongiae). Int J. Invert. Reprod. Dev. (Amsterdam) 9: 1-11.

Gaino, E., Burlando, B. and Buffa, P. 1987. Ultrastructural study of oogenesis and fertilization in Sycon ciliatum (Porifera, Calsispongiae). Int. J. Invert. Reprod. Dev. 11: 73-82.

Haris, A. 2005. Pertumbuhan, Sintasan, Perkembangan Gamet, dan Bioaktifitas Ekstrak dan Farkasi Spons Schmidt yang Ditransplantasikan pada Lingkungan Berbeda. Disertasi. Program Pasca Sarjana, Institut Pertanian Bogor. Bogor. Tidak dipublikasikan.

Hoppe, W.F. 1988. Reproductive pattern in three species of large coral reef sponges. Coral Reef. 45-50.

Hoppe, W.F. and Reichert, M.J.M. 1987. Predictable annual mass release of gametes by the coral reef sponge Neofibularia nolitangere (Porifera, Demospongiae). Mar. Biol. 94: 277286.

Kaye, H.R. and Reiswig, H.M. 1991. Sexual Reproduction in Four Carribean commercial sponges. I. Reproductive cycles and spermatogenesis. Invert. Reprod. Dev. 19: 111 .

Mariani, S., Uriz, M.J. and Turon, X. 2000. Larval bloom of the oviparous sponge Cliona viridis: coupling of larval abundance and adult distribution. Mar. Biol. 137: 783-790.
Meros-Fine, E., Shefer, S. and Ilan, M. 2005. Changes in morphology and physiology of an east Mediteranean sponge in different habitat. Mar Biol. 147: 243-250.

Rani, C. 2004. Reproduksi Seksual Karang Skleraktina Acropora nobilis dan Pocillopora verrucosa di Terumbu Karang Tropik P. Barang Lompo Makassar. Desertasi. Institut Pertanian Bogor. Tidak Dipublikasikan.

Ritson-Wiliam, R., Becerro, M.A. and Paul, V.J. 2005. Spawning of the giant barrel sponge Xetospongia muta in Belize. Coral Reefs 24: 160.

Sara, M. 1992. Porifera. In: Adiyodi, K.G. \& Adiyodi, R.G. (Eds.). Reproductive Biology of Invertebrates. Volume (V): 1-29. Sexual Differentiation and Behavior. New York: Jhon Wiley \& Sons Chisester.

Simpson, T.L. 1984. The Cell Biology of Sponges. Springer Verlag, New York. 662 pp.

Sidri, M. 2004. Chondrilla nucula (Porifera, Demospongiae): an example of successful plasticity. Moephological and ecological aspects. Ph.D. Thesis, University of Stuttgart, Stuttgart, Germany.

Sidri, M., Milanese, M. and Bummer, F. 2005. First observation on egg release in the oviparous sponge Chondrilla nucula (Demospongiae, Chondrosida, Chondrillidae) in The Mediteranean Sea. Inverteb. Biol. 124 (2): 9197.

Tomascik, T., Mah, A.J., Nontji, A. and Moosa, M.K. 1997. The ecology of The Indonesian Seas. Part I Chapter 1-2. Periplus edition.

Tanner, J.E. 1996. Seasonality and lunar periodecity in the reproduction of Pocilloporid Corals. Coral Reefs. 15: 59-66.

Usher, K.M., Kuo, J., Fromont, J. and Sutton, D.C. 2001. Vertical Transmission of Cyanobacterial symbiont in the marine sponge Chondrilla australiensis (Demospongiae). Hydrobiologia 461: 15-23.

Witte, U., Bartel, D. and Tendal, O. 1994. The reproductive cycle of the sponge Halichondria panacea Pallas (1766) and its relationship to temperatura and salinity. J. exp mar Biol. Ecol. 183: 41-52. 